\title{
Persoalan Kriteria Batasan Pertanggungjawaban Pidana Korporasi: Tinjauan Terhadap Peraturan Mahkamah Agung Nomor 13 Tahun 2016
}

\author{
Nur Aripkah \\ Fakultas Hukum Universitas Diponegoro \\ Jl. Imam Bardjo, S.H., No. 1-3, Kampus Pleburan, Semarang, Indonesia \\ arifkahrika@gmail.com
}

Received: 1 Januari 2020; Accepted: 11 Juni 2020; Published: 25 Agustus 2020

DOI: 10.20885/iustum.vol27.iss2.art8

\begin{abstract}
The formulation contained in Article 4 paragraph (2) of Supreme Court Regulation (Perma) No. 13 of 2016 concerning Procedures for Handling Criminal Cases by Corporations, especially those related to the element of determining errors in corporate criminal liability, still creates confusion and legal debate in it. As in addition to the element of actus reus (action) which is synonymous with criminal responsibility, there is an element of mens rea (error) which is also very essential and closely related to criminal liability. Thus in this research the study is focused on the problem of the criteria for limiting corporate criminal liability in accordance with Perma No. 13 of 2016 and the theory of corporate criminal responsibility contained in the Perma. The research method used is normative with a statutory, conceptual, and case approach. In the research it was found that the problem of the criteria for limiting corporate criminal liability as stipulated in Perma No. 13 of 2016 lies in the unclear and non strict standards of the criteria to regulate corporate criminal liability and this issue can be viewed from the vicarious liability theory and corporate culture model theory.
\end{abstract}

Key Words: Corporation; criminal liability; limitation criteria

Abstrak

Rumusan yang tertuang dalam Pasal 4 ayat (2) Perma No. 13 Tahun 2016 tentang Tata Cara Penanganan Perkara Tindak Pidana Oleh Korporasi khususnya yang berkaitan dengan unsur penentuan kesalahan dalam pertanggungjawaban pidana korporasi masih menimbulkan kerancuan dan perdebatan hukum di dalamnya. Karena selain unsur actus reus (perbuatan) yang identik dengan pertanggungjawaban pidana, maka ada unsur mens rea (kesalahan) yang juga sangat esensial dan begitu lekat dengan pertanggungjawaban pidana. Dengan demikian pada penelitian ini kajian difokuskan pada persoalan kriteria batasan pertanggungjawaban pidana korporasi ditinjau dari Perma No. 13 Tahun 2016 dan teori pertanggungjawaban pidana korporasi yang termuat dalam Perma tersebut. Adapun metode penelitian yang digunakan adalah normatif dengan pendekatan undangundang, konseptual, dan kasus. Dalam penelitian disimpulkan bahwa persoalan kriteria batasan pertanggungjawaban pidana korporasi yang tertuang dalam Perma No. 13 Tahun 2016 terletak pada tidak jelasnya dan tidak tegasnya tolak ukur kriteria pertanggungjawaban pidana korporasi yang diatur dan persoalan tersebut dapat ditinjau dari teori vicarious liability dan teori corporate culture model.

Kata-kata Kunci: Korporasi; pertanggungjawaban pidana; kriteria batasan 


\section{Pendahuluan}

Diakuinya korporasi sebagai subjek hukum pidana menunjukkan dapat dibebankannya pertanggungjawaban secara pidana kepada korporasi. Dikatakan oleh Muladi dan Dwidja Priyatno bahwa di dalam hukum positif kita, korporasi sebagai pelaku tindak pidana dapat dipertanggungjawabkan secara pidana dan dapat dijatuhkan pidana. ${ }^{1}$ Hal ini dibuktikan dengan diaturnya tindak pidana korporasi dalam peraturan perundangan-undangan khusus, seperti UndangUndang Nomor 31 Tahun 1999 jo. Undang-Undang Nomor 20 Tahun 2001 tentang Pemberantasan Tindak Pidana Korupsi, Undang-Undang Nomor 32 Tahun 2009 tentang Perlindungan dan Pengelolaan Lingkungan Hidup, Undang-Undang Nomor 8 Tahun 2010 tentang Pemberantasan Tindak Pidana Pencucian Uang, dan peraturan perundang-undangan khusus lainnya. Kitab Undang-Undang Hukum Pidana (KUHP) ternyata tidak mengatur korporasi sebagai subjek hukum pidana, begitupun dengan Undang-Undang Nomor 8 Tahun 1981 tentang Hukum Acara Pidana atau dikenal dengan istilah Kitab Undang-Undang Hukum Acara Pidana (KUHAP). Kedua peraturan tersebut belum mendudukkan korporasi sebagai subjek dalam hukum pidana.

Menyadari tidak diaturnya korporasi sebagai subjek dalam hukum pidana di dalam KUHP dan KUHAP, di Indonesia saat ini telah hadir Peraturan Mahkamah Agung Nomor 13 Tahun 2016 tentang Tata Cara Penanganan Perkara Tindak Pidana oleh Korporasi (Perma No. 13 Tahun 2016). Tentunya, hal ini menjadi bagian dari salah satu usaha untuk memformulasikan kebijakan hukum pidana terhadap kejahatan korporasi.

Pasal 3 Perma No. 13 Tahun 2016 telah memberikan definisi terkait dengan tindak pidana korporasi, yaitu tindak pidana yang dilakukan oleh atau berdasarkan hubungan kerja, atau berdasarkan hubungan lain, baik sendirisendiri maupun bersama-sama yang bertindak untuk korporasi di dalam maupun di luar lingkungan korporasi. Makna hubungan kerja di sini dapat dilihat dalam Pasal 1 angka 11 Perma No. 13 Tahun 2016 tentang Tata Cara Penangan Perkara Tindak Pidana Oleh Korporasi, yaitu hubungan antara korporasi dengan pekerja

${ }_{1}^{1}$ Muladi dan Dwidja Priyatno, Pertanggungjawaban Pidana Korporasi, Prenadamedia Group, Jakarta, 2010, 
atau pegawainya berdasarkan perjanjian yang mempunyai unsur pekerjaan, upah, maupun perintah.

Perma No. 13 Tahun 2016 dengan tegas memuat bahwa korporasi sebagai subjek hukum dapat dimintai pertanggungjawaban pidana. Berdasarkan Pasal 4 ayat (2) Perma No. 13 Tahun 2016, korporasi dapat dipersalahkan apabila korporasi (a) memperoleh keuntungan atau manfaat dari tindak pidana tertentu atau suatu tindak pidana dilakukan untuk kepentingan korporasi, (b) membiarkan terjadinya tindak pidana, atau (c) tidak melakukan langkah-langkah yang diperlukan untuk melakukan pencegahan, mencegah dampak yang lebih besar, dan memastikan kepatuhan terhadap ketentuan hukum yang berlaku guna menghindari terjadinya tindak pidana.

Korporasi sebagai suatu entitas hukum tentunya memberikan kontribusi besar dalam perekonomian negara, tetapi di sisi lain korporasi ada kalanya juga melakukan tindak pidana yang membawa kerugian terhadap negara², seperti halnya kasus PT Duta Graha Indah (PT DGI) yang terungkap pada 2017. Dalam kasus ini, Dudung Purwadi selaku Direktur Utama PT DGI bersama dengan Nazaruddin dan Made Meregawa melakukan kesepakatan dalam pengaturan proyek pembangunan rumah sakit khusus infeksi dan pariwisata Universitas Udayana pada 2009 dan 2010. Kesepakatan dilakukan dalam rangka memenangkan PT DGI sebagai pelaksana pekerjaan (rekanan). ${ }^{3}$ Dalam Putusan Pengadilan Negeri Jakarta Pusat Nomor 94/Pid.Sus-TPK/2017/PN.Jkt.Pst, Komisi Pemberantasan Korupsi (KPK) menetapkan Purwadi sebagia tersangka, yang oleh Pengadilan Negeri Tipikor Jakarta Pusat dijatuhkan pidana penjara dan denda. Selain itu, Pengadilan Negeri Tipikor Jakarta Pusat juga menjatuhkan pidana tambahan kepada PT DGI berupa pembayaran uang pengganti.

Berangkat dari hal tersebut, masih terdapat ketidakjelasan dalam menerapkan kriteria batasan pertanggungjawaban pidana korporasi, yakni kapan sebenarnya pidana harus dibebankan kepada pengurus dan kapan pidana harus

${ }^{2}$ Hari Sitra Disemadi dan Nyoman Serikat Putra Jaya. "Perkembangan Pengaturan Korporasi Sebagai Subjek Hukum Pidana Di Indonesia." Jurnal Hukum Media Bhakti, Vol. 3, No. 2, 2019, hlm. 119.

3 Fajar Pebrianto, "Eks Dirut PT DGI Dudung Purwadi Divonis 4 Tahun 8 Bulan Bui," 2017, https:/ / nasional.tempo.co/read/1037507/eks-dirut-pt-dgi-dudung-purwadi-divonis-4-tahun-8-bulan-bui., diakses pada 18 November 2018 
dibebankan kepada korporasi. Hal ini tergambar dari tidak diposisikannya PT DGI sebagai tersangka dalam kasus tersebut. Padahal, dalam Nomor 94/Pid.SusTPK/2017/PN.Jkt.Pst, Purwadi terbukti melakukan suatu tindak pidana yang menguntungkan korporasi, bukan untuk menguntungkan diri pribadi. Di sini, korporasi yang tidak dijadikan sebagai tersangka sejak awal justru dibebankan pidana tambahan berupa uang pengganti.

\section{Rumusan Masalah}

Berdasarkan pemaparan latar belakang di atas, penelitian ini akan difokuskan pada pertanyaan berikut: apa yang menjadi persoalan terkait kriteria batasan pertanggungjawaban pidana korporasi ditinjau dari Perma No. 13 Tahun 2016? Teori pertanggungjawaban pidana korporasi apa yang termuat dalam Perma No. 13 Tahun 2016?

\section{Tujuan Penelitian}

Penelitian ini bertujuan untuk mengetahui persoalan terkait kriteria pertanggungjawaban pidana korporasi ditinjau dari Perma No. 13 Tahun 2016 dan teori-teori pertanggungjawaban pidana korporasi apa yang termuat dalam Perma No. 13 Tahun 2016.

\section{Metode Penelitian}

Metode penelitian yang digunakan pada penelitian ini adalah metode penelitian hukum normatif dengan pendekatan undang-undang, konseptual, dan kasus. Penggunaan data pada penelitian ini menitikberatkan pada data sekunder berupa bahan hukum primer, sekunder, dan tersier. Metode pengumpulan data sekunder menggunakan studi pustaka dan teknik analisis data yang digunakan adalah analisis kualitatif dengan penafsiran gramatikal dan sistematis. Penafsiran gramatikal merupakan penafsiran untuk mengetahui makna ketentuan peraturan perundang-undangan dengan menguraikan bahasa, susunan, dan/atau bunyi. Sedangkan penafsiran sistematis merupakan penafisran undang-undang sebagai bagian dari keseluruhan sistem peraturan perundang-undangan dengan menghubungkan undang-undang lain. 


\section{Hasil Penelitian dan Pembahasan}

\section{Persoalan Kriteria Batasan Pertanggungjawaban Pidana Korporasi Ditinjau dari Perma No. 13 Tahun 2016}

Pertanggungjawaban pidana korporasi dalam hukum pidana bukan merupakah persoalan yang mudah, mengingat bahwa korporasi adalah badan hukum. Permasalahan ini berpangkal pada asas tiada pidana tanpa kesalahan. Menentukan kesalahan (schuld, mens rea) korporasi dalam suatu tindak pidana tidak mudah karena terdapat hubungan yang begitu kompleks di antara dewan direksi (board of directors), eksekutif, dan manajer pada satu sisi, dan perusahaan induk (parent corporations), divisi-divisi perusahaan (corporate divisions), dan cabang-cabang perusahaan (subsidiaries) pada sisi lainnya. ${ }^{4}$

Kesalahan (mens rea) merujuk pada sikap kalbu yang secara alamiah hanya ada pada orang alamiah. Mens rea adalah unsur yang sulit dibuktikan dari korporasi yang dianggap melakukan tindak pidana mengingat korporasi hanya dapat melakukan tindakan melalui organ-organ atau pengurusnya. Korporasi dapat dianggap melakukan tindak pidana berdasarkan perbuatan yang dilakukan oleh orang yang mengontrol pengurusan korporasi.

Pada penjabaran sebelumnya telah dijelaskan bahwa dalam Pasal 3 Perma No. 13 Tahun 2016, tindak pidana korporasi didefinisikan sebagai tindak pidana yang dilakukan berdasarkan hubungan kerja atau hubungan lain, yang bertindak secara sendiri-sendiri ataupun bersama-sama untuk dan atas nama korporasi di dalam maupun di luar lingkungan korporasi. Sementara hubungan kerja yang dimaksud adalah hubungan antara korporasi dengan pekerja atau pegawainya berdasarkan perjanjian yang mempunyai unsur pekerjaan, upah, dan perintah. Dengan kata lain, hubungan antara pekerja dan korporasi terjadi setelah diadakan perjanjian, yaitu perjanjian tentang kesanggupan pegawai untuk menerima upah dan korporasi sanggup mempekerjakan pekerja atau pegawai dengan membayar upah.

${ }^{4}$ Budi Suhariyanto, "Kedudukan Peraturan Mahkamah Agung Nomor 13 Tahun 2016 Dalam Mengatasi Kendala Penanggulangan Tindak Pidana Korporasi”, Negara Hukum: Membangun Hukum Untuk Keadilan Dan Kesejabteraan Vol. 9, No. 1, Juni 2018, hlm. 109 
Tindak pidana korporasi tidak hanya terkait dengan hubungan kerja, tetapi ada juga dalam bentuk hubungan lain, yaitu hubungan antara pengurus dan korporasi atau dengan korporasi lain sehingga menjadikan pihak lain tersebut bertindak untuk kepentingan pihak pertama berdasarkan perikatan, baik tertulis maupun tidak tertulis. ${ }^{5} \mathrm{Jadi}$, ada dua hal yang harus diperhatikan dalam tindak pidana korporasi, yaitu terdapat tindak pidana yang dilakukan berdasarkan hubungan kerja dan tindak pidana yang dilakukan dengan berdasarkan hubungan lain.

Seperti kasus yang telah dipaparkan sebelumnya bahwa Purwadi merupakan Direktur Utama PT DGI. Artinya, ia merupakan pihak dari korporasi atau merupakan pengurus dari PT DGI, sementara Nazaruddin dan Made Megawana bukanlah bagian dari pengurus PT DGI, namun dalam hal ini mereka membuat kesepakatan dengan Purwadi untuk memenangkan PT DGI dalam proyek pembangunan RS Universitas Udayana. Inilah yang dinamakan dengan tindak pidana korporasi berdasarkan hubungan lain yang tidak hanya melibatkan pengurus korporasi, tetapi juga melibatkan orang yang bukan menjadi bagian dari kepengurusan korporasi. Orang yang dapat dikatakan sebagai pengurus atau pengendali korporasi jika kita merujuk pada teori organ adalah orang yang mengendalikan perusahaan, baik sendiri maupun bersama-sama yang dalam hal ini dipandang sebagai pengendali perusahaan yang didalamnya terdiri dari para direktur dan manajer. ${ }^{6}$ Lain halnya jika kita merujuk ke Pasal 1 angka 2 UndangUndang Nomor 40 Tahun 2007 tentang Perseroan Terbatas (UU PT) yang mendefinisikan organ perseoran terdiri dari Rapat Umum Pemegang Saham, Direksi, dan Dewan Komisaris.

Indikator kesalahan korporasi telah diatur pada Pasal 4 ayat (2) Perma No. 13 Tahun 2016. Ditegaskan bahwa dalam menjatuhkan pidana terhadap korproasi, hakim dapat menilai kesalahan korporasi dari tiga aspek, yakni:

1. Korporasi dapat memperoleh keuntungan atau manfaat dari tindak pidana atau tindak pidana dilakukan untuk kepentingan korporasi. Dalam hal ini,

${ }^{5}$ Sutan Remy Sjahdeini, Ajaran Pemidanaan Tindak Pidana Korporasi \& Seluk Beluknya, Edisi Kedua, Kencana, Jakarta, 2017, hlm. 244

${ }^{6}$ Barda Nawawi Arief, Bunga Rampai Kebijakan Hukum Pidana (Perkembangan Penyusunan Konsep KUHP Baru), Prenadamedia Group, Jakarta, 2016, hlm. 246 
Perma No. 13 Tahun 2016 tidak menjelaskan lebih lanjut keuntungan yang seperti apa yang dapat dikategorikan sebagai keuntungan korproasi, apakah keuntungan tersebut secara langsung atau secara tidak langsung yang diperoleh korporasi dari salah satu organ pengurusnya yang melakukan tindak pidana? Walaupun misalnya, korporasi tidak mengetahui tindak pidana yang dilakukan oleh pengurusnya, namun tindak pidana tersebut secara tidak langsung juga memberikan keuntungan kepada korporasi;

2. Korporasi membiarkan terjadinya tindak pidana. Dalam hal ini, Perma No. 13 Tahun 2016 juga tidak memberikan penjelasan yang lebih lanjut mengenai definisi atau arti korporasi telah membiarkan terjadinya tindak pidana. Apabila dihubungkan dengan syarat kesalahan, maka dapat dilihat, apakah suatu korporasi dalam menjalankan usahanya selalu mengambil jarak sejauh mungkin dengan terjadinya suatu tindak pidana? Atau dengan kata lain, apakah sebelumnya korporasi telah memperhitungkan sedemikian rupa perbuatan-perbuatannya yang dapat mengakibatkan terjadinya suatu tindak pidana di kemudian hari?; dan

3. Korporasi tidak melakukan langkah-langkah yang diperlukan untuk melakukan pencegahan, mencegah dampak yang lebih besar, dan memastikan kepatuhan terhadap ketentuan hukum yang berlaku guna menghindari terjadinya tindak pidana. Dalam hal ini, hampir sama dengan aspek pertama dan kedua, Perma No. 13 Tahun 2016 juga tidak memberi klarifikasi lebih lanjut mengenai langkah-langkah pencegahan seperti apa yang dapat dikategorikan sebagai bagian dari tindak pidana korporasi, serta prinsip kepatuhan hukum apa yang dimaksud dalam aturan ini. Pasalnya, apabila berbicara mengenai prinsip kepatuhan hukum, ada dua hal yang dipertanyakan, yaitu apakah (a) prinsip kepatuhan hukum oleh pengurus terhadap kebijakan yang dikeluarkan oleh korporasi? Atau (b) prinsip kepatuhan hukum oleh korporasi terhadap peraturan perundang-undangan?

Berdasarkan ulasan di atas, rumusan terkait penentuan kesalahan dalam pertanggungjawaban pidana korporasi yang tertuang dalam Perma No. 13 Tahun 2016 masih menimbulkan kerancuan dan perdebatan hukum di dalamnya. Ini 
karena selain unsur actus reus (perbuatan), ada unsur mens rea (kesalahan) yang juga sangat esensial dan begitu lekat dengan pertanggungjawaban pidana. ${ }^{7}$

Ketidakjelasan unsur kesalahan di atas tentunya berimplikasi juga pada ketidakjelasan kriteria batasan pertanggungjawaban pidana korporasi yang terdapat dalam peraturan ini. Oleh karena itu, untuk mengetahui kriteria batasan pertanggungajawaban pidana korporasi dalam peraturan Mahkamah Agung tersebut, artikel ini akan menganalisisnya dari dua sudut pandang teori, yaitu teori vicarious liability dan corporate culture model.

\section{Pertanggungjawaban Pidana Korporasi dalam Perma No. 13 Tahun 2016 ditinjau dari Teori Vicarious Liability}

Berkaitan dengan unsur kesalahan yang terdapat pada Pasal 4 ayat (2) huruf a dan b Perma No. 13 Tahun 2016 yang mengarah kepada pertanggungjawaban vicarious liability. Barda Nawawi Arief berpendapat bahwa dalam vicarious liability, seseorang dapat dipertanggungjawabkan atas perbuatan dan kesalahan orang lain. ${ }^{8}$ Pertanggungjawaban dapat dimintakan apabila mens rea dari orang yang berasosiasi dengan korporasi dalam melakukan tindak pidana dengan sengaja dan bertujuan untuk menguntungkan korporasi. ${ }^{9}$ Pada dasarnya, doktrin vicarious liability didasarkan atas employment principle, yang berarti dalam hal ini majikan (employer) adalah penanggung jawab utama dari perbuatan para buruhnya atau karyawannya. ${ }^{10}$

Apabila karyawan tersebut sudah terbukti melakukan tindak pidana dengan tujuan menguntungkan korporasi, maka korporasi harus bertanggung jawab tanpa perlu pembuktian adanya perintah dari pengurus korporasi dalam melakukan tindak pidana tersebut.11 Ini karena korporasi telah diposisikan sebagai pemberi kerja (employer) yang bertanggung jawab secara vikarius atas perbuatan-perbuatan dari bawahannya. Dengan demkian, berdasarkan

\footnotetext{
7 Fitriani Rahmadia, Hari Sutra Disemadi, and Nyoman Serikat Putra Jaya. "Criminal Liability in Environmental Crimes Committed by Corporations after the Supreme Court Regulation Number 13 of 2016 at Indonesia." Unram Law Review Vol. 4, No. 1, 2020, hlm. 3.

${ }^{8}$ Barda Nawawi Arief, Perbandingan Hukum Pidana Edisi Revisi, PT Rajagrafindo Persada, Jakarta, 2019, hlm. 151

9 Ibid.

${ }^{10}$ Kristian, "Urgensi Pertanggungjawaban Pidana Korporasi”, Jurnal Hukum \& Pembangunan Vol. 44 No. 4 Desember 2014, hlm. 608

${ }^{11}$ Ibid, hlm. 610
} 
pertanggungjawaban vikarius, korporasi dimungkinkan dibebani pertanggungjawaban pidana atas perbuatan-perbuatan yang dilakukan oleh para pegawai, kuasa, atau mandatarisnya, atau siapapun yang bertanggung jawab terhadap korporasi tersebut. ${ }^{12}$ Korporasi hanya dapat menghindari tanggung jawab apabila dapat membuktikan bahwa korproasi tersebut sudah melakukan upaya yang sesuai untuk mencegah terjadinya tindak pidana tersebut. Melalui pendekatan delik kegagalan mencegah tersebut, kesalahan pegawai menjadi kesalahan korporasi sehingga mens rea pengurus adalah mens rea korporasi. Dengan kata lain, mens rea pekerja atau pegawai diatributkan kepada korporasi. ${ }^{13}$

Seperti yang terjadi pada kasus PT DGI, dalam hal ini yang diposisikan sebagai tersangka maupun terdakwa adalah Purwadi, Direktur Utama PT DGI. Namun, dalam pertimbangan hukum dalam Putusan Pengadilan Negeri Jakarta Pusat Nomor 94/Pid.Sus-TPK/2017/PN.Jkt.Pst, majelis hakim menyatakan bahwa Purwadi selaku Direktur Utama adalah salah satu orang yang hanya turut serta melakukan kejahatan atau sebagai medepleger. Selain itu, pertimbangan hakim juga menyatakan bahwa selama persidangan tidak ada fakta yang dapat membuktikan jika perbuatan yang dilakukan oleh Purwadi ditujukan untuk memperkaya dirinya sendiri, melainkan hanya untuk menguntungkan korporasi, yaitu memenangkan PT DGI untuk mendapatkan proyek dalam proses lelang. Pada amar putusan, hakim juga menyatakan bahwa pidana pengganti tidak dibebankan kepada Purwadi, tetapi dibebankan kepada PT DGI selaku korporasi yang mendapatkan keuntungan dari tindak pidana yang dilakukan oleh Purwadi. ${ }^{14}$

Kasus PT DGI seharusnya mutlak dikatakan sebagai tindak pidana korporasi sehingga yang seharusnya menjadi tersangka dan terdakwa utama adalah korporasi, bukan Purwadi. Ini tentu relevan jika dikaitkan dengan teori vicarious liability dan juga aturan yang terdapat dalam Pasal 4 ayat (2) huruf a dan b Perma No. 13 Tahun 2016. Sebagaimana dikatakan Gobert, bahwa kriteria yang

12 Sutan Remy Sjahdeini., Op. Cit., hlm. 158

${ }^{13}$ Lakso Anindito, "Lingkup Tindak Pidana Korupsi Dan Pembuktian Kesalahan Dalam Sistem Pertanggungjawaban Pidana Korporasi Di Indonesia, Inggris, Dan Perancis”, Integritas Jurnal Anti Korupsi Vol. 3 No. 1, Maret 2017, hlm. 21

${ }^{14}$ Ibid., hlm. 720 
penting untuk dibuktikan dalam vicarious liability adalah pada saat melakukan tindak pidana, pelaku sedang mengerjakan urusan korporasi dan tindak pidana tersebut dilakukan untuk mewujudkan kepentingan korporasi. ${ }^{15}$

Berdasarkan kriteria pertanggungjawaban pidana korporasi yang terdapat dalam Pasal 4 ayat (2) huruf a dan b Perma No. 13 Tahun 2016, jika ditinjau dari teori vicarious liability, maka ada beberapa hal yang dapat dijadikan sebagai batasan untuk menentukan pertanggungjawaban pidana korporasi, yaitu:

\section{Harus terdapat hubungan seperti hubungan pengurus dengan korporasi dan hubungan pekerjaan antara pekerja/pegawai dengan korporasi}

Pada kriteria ini terdapat dua hubungan, yaitu hubungan pengurus dengan korporasi dan hubungan pekerjaan antara pekerjaan/pegawai dengan korporasi. Menurut definisi yang diberikan Pasal 1 angka 10 Perma No. 13 Tahun 2016, pengurus merupakan organ korporasi yang menjalankan pengurusan korporasi sesuai dengan anggaran dasar atau undang-undang yang berwenang mewakili korporasi, termasuk mereka yang tidak memiliki kewenangan untuk mengambil keputusan, namun dalam kenyataannya dapat mengendalikan atau turut mempengaruhi kebijakan korporasi serta turut memutuskan kebijakan dalam korporasi yang dapat dikualifikasikan sebagai tindak pidana. Adapun yang dimaksud dengan organ korporasi, menurut Pasal 1 angka 2 UU PT adalah Rapat Umum Pemegang Saham (RUPS), direksi, dan dewan komisaris. Hubungan hukum antara seorang pengawai atau pekerja dengan korporasi adalah hubungan yang bersifat atasan-bawahan atau hubungan yang bersifat subordinasi. Sedangkan hubungan antara pengurus dan korporasi disebut dengan hubungan kepercayaan (fiduciary duty) yang bersifat koordinasi, tidak ada atasan-bawahan.

Menurut Pasal 92 ayat (1) UU PT, tugas dan tanggung jawab adalah menjalankan pengurusan perseroan. Pada Pasal 97 ayat (2) UU PT, ditegaskan bahwa direksi mempunyai kewajiban menjalankan kepengurusan dengan itikad baik dan penuh tanggung jawab. Pelanggaran terhadap ketentuan ini dapat menyebabkan direksi bertanggung jawab secara pribadi apabila yang bersangkutan lalai dalam menjalankan tugasnya. Sedangkan dewan komisaris

${ }^{15}$ Andri G. Wibisana, "Kejahatan Lingkungan Oleh Korporasi: Mencari Bentuk Pertanggungjawaban Korporasi Dan Pemimpin/Pengurus Korporasi Untuk Kejahatan Lingkungan Di Indonesia”, Jurnal Hukum \& Pembangunan Vol. 46 No. 2, April-Juni 2016, hlm. 156 
dalam Pasal 108 ayat (1) UU PT dijelaskan tugasnya adalah melakukan pengawasan atas kebijakan pengurusan, jalannya pengurusan pada umumnya, baik mengenai perseoran maupun usaha perseroan, dan memberi nasihat kepada direksi.

Jadi, berdasarkan kriteria ini, yang terpenting diperhatikan adalah terdapat hubungan yang jelas antara pengurus dengan korporasi serta pegawai atau pekerja dengan korporasi. Hal ini penting dalam prinsip pertanggungjawaban berdasarkan teori vicarious liability karena nantinya dapat menentukan apakah korporasi dapat dipertanggungjawabkan secara pengganti terhadap orang yang berasosiasi dalam korporasi tersebut atau tidak.

\section{Tindak pidana yang dilakukan oleh pekerja atau pengurus tersebut harus berkaitan atau masih dalam ruang lingkup pekerjaannya}

Apabila berbicara mengenai ruang lingkup pekerjaan, maka tentu maknanya bisa sangat luas. Dalam kriteria ruang lingkup pekerjaan ini, yang harus diperhatikan adalah bahwa pengurus maupun pegawai atau pekerja memiliki otoritas nyata untuk melakukan pekerjaannya. Otoritas yang dimaksud adalah bahwa korporasi secara sengaja memberikan otoritas atau wewenang kepada pengurus dan pegawai atau pekerja lainnya untuk melakukan suatu tindakan yang mengatasnamakan korporasi.

Kesalahan korporasi dalam hal ini dapat dilihat, bahwa yang dikerjakan para pengurus dan pegawai atau pekerjanya masih dalam ruang lingkup pekerjaan korporasi; pekerjaan yang mengatasnamakan korporasi dan diperuntukkan bagi korporasi. Seperti yang telah disinggung sebelumnya bahwa masing-masing organ perseroan, termasuk direksi, dewan komisaris, serta RUPS memiliki fungsi dan wewenang masing-masing dalam tubuh perseroan, yang ruang lingkup pekerjaannya masing-masing yang telah diatur dalam UU PT dan juga pastinya berdasarkan akta pendirian perusahaan. Dengan kata lain, selama para pengurus dan pegawai atau pekerja bekerja sesuai dengan standart operational procedure (SOP) korporasi, maka apabila terjadi suatu tindak pidana dikemudian hari, tetap yang dipertanggungjawabkan secara pidana adalah korporasinya. Dengan demikian, dapat dikatakan, pada kriteria ini, mens rea pengurus dan pegawai atau pekerja diatributkan pada korporasi. 


\section{Tindak pidana tersebut ditujukan untuk kepentingan korporasi, bukan} kepentingan pribadi pengurus

Membahas mengenai kepentingan korporasi, maka dalam hal ini tindak pidana yang dilakukan oleh pegawai atau pengurus korporasi memang ditujukan untuk kepentingan korporasi secara langsung, yang berarti dari tindak pidana yang dilakukan pengurus dan pegawai atau pekerja secara sengaja dilakukan untuk menguntungkan korporasi. Dengan kata lain, dari awal sudah menjadi tujuan bahwa tindak pidana tersebut dilakukan untuk korporasi.

Berbicara keuntungan, pastinya juga menimbulkan suatu pertanyaan. Keuntungan yang bagaimana dapat dikategorikan sebagai keuntungan korporasi? Dalam hal ini, tentunya ada yang dinamakan keuntungan secara langsung dan tidak langsung. Maksud dari keuntungan secara langsung adalah bahwa korporasi memang menerima sejumlah keuntungan, misalnya dividen yang didapatkan korporasi berasal dari tindak pidana atau korporasi melakukan penggelapan terhadap dividen yang seharusnya dibagikan kepada para pemegang saham yang berasal dari laba bersih perusahaan. Sedangkan keuntungan secara tidak langsung yang dimaksud dalam hal ini adalah tindak pidana yang tanpa disadari dilakukan oleh pegawai atau pengurus secara tidak langsung memberikan keuntungan pada korporasi. Namun, pembuktian mengenai keuntungan secara langsung dan tidak langsung hanya dapat dibuktikan pada saat persidangan.

Pasal 104 ayat (4) huruf c UU PT telah mengatur bahwasannya direksi tidak dapat dipertanggungjawabkan secara pribadi selama ia tidak mempunyai benturan kepentingan, baik langsung maupun tidak, atas tindakan kepengurusan yang merugikan. Berdasarkan kriteria ini, maka perbuatan dari pengurus dan pegawai atau pekerja tidak begitu diperhitungkan, yang menjadi pertimbangan adalah apakah tindak pidana yang dilakukan itu bertujuan untuk kepentingan diri pribadi atau korporasi. Jika bertujuan untuk kepentingan diri pribadi ataupun menguntungkan secara pribadi, tentu pertanggungjawabannya juga secara pribadi. Namun sebaliknya, jika tindak pidana dilakukan untuk kepentingan korporasi, maka pertanggungjawaban pidana berada pada korporasi. 
Pertanggungjawaban Pidana Korporasi dalam Perma No. 13 Tahun 2016 Ditinjau dari Corporate Culture Model

Terkait unsur kesalahan yang terdapat pada Pasal 4 ayat (2) huruf c Perma No. 13 Tahun 2016, dinyatakan bahwa "korporasi dapat dipersalahkan apabila tidak melakukan langkah-langkah yang diperlukan untuk melakukan pencegahan, mencegah dampak yang lebih besar dan memastikan kepatuhan terhadap ketentuan hukum yang berlaku guna menghindari terjadinya tindak pidana." Seperti yang dikemukakan oleh De Maglie bahwa berdasarkan teori corporate culture model terdapat kemungkinan untuk menjerat korporasi berdasarkan teori model budaya korporasi, yaitu adanya kebijakan korporasi (corporate policy), adanya kesalahan korporasi dalam pencegahan (preventative fault), dan adanya kesalahan korporasi dalam merespon tindak pidana (reactive corporate fault). ${ }^{16}$ Dengan kata lain, Pasal 4 ayat (2) huruf c tersebut dapat kita tinjau dari corporate culture model. Berdasarkan teori corporate culture model, pertanggungjawaban pidana korporasi dapat dilihat dari dari prosedur, sistem bekerjanya, ataupun budaya dari korporasi yang bersangkutan. ${ }^{17}$

Teori corporate culture model memfokuskan pada kebijakan korporasi, baik yang tersurat maupun tersirat, yang mempengaruhi mekanisme kerja suatu korporasi. ${ }^{18}$ Suatu korporasi dapat dipertanggungjawabkan secara pidana apabila tindakan seseorang memiliki alasan yang rasional; bahwa korporasi memberikan wewenang atau mengizinkan perbuatan tercela tersebut dilakukan. ${ }^{19}$ Apabila melihat lagi kasus PT DGI, maka dapat juga ditinjau dari teori corporate culture model yang rumusan pengaturannya terdapat pada Pasal 4 ayat (2) huruf c Perma. No. 13 Tahun 2016. Dalam hal ini, PT DGI telah melabrak beberapa aturan, yakni Peraturan Pemerintah Nomor 29 Tahun 2000 tentang Penyelenggaraan Jasa Konstruksi, khususnya Pasal 55, yang telah melarang dilakukannya persekongkolan untuk mengatur dana atau menentukan pemenang dalam

${ }^{16}$ Andri G. Wibisana, Op. Cit., hlm. 158.

${ }^{17}$ Kristian, Sistem Pertanggungjawaban Pidana Korporasi (Tinjauan Teoritis Dan Perbandingan Hukum Di Beberapa Negara), PT Refika Aditama, Bandung, 2016, hlm. 100.

${ }^{18}$ Hariman Satria, "Pertanggungjawaban Pidana Korporasi Dalam Tindak Pidana Korupsi", Jurnal Mimbar Hukum Vol. 28 No. 2, Juni 2016, hlm. 296.

${ }^{19}$ Eddy O.S Hiariej, Prinsip-Prinsip Hukum Pidana, Cahaya Atma Pusaka, Yogyakarta, 2016, hlm. 165. 
pelelangan umum ataupun pelelangan terbatas sehingga mengakibatkan persaingan usaha tidak sehat.

Seperti pada kasus ini terjadi persekongkolan untuk memenangkan PT DGI dalam pelelangan harga proyek pembangunan rumah sakit khusus infeksi dan pariwisata Universitas Udayana Tahun Anggaran 2009 dan 2010. Kemudian, aturan yang terdapat dalam Pasal 5 Keputusan Presiden (Keppres) Nomor 80 Tahun 2003 tentang Pedoman Pelaksanaan Pengadaan Barang/Jasa Pemerintah sebagaimana telah beberapa kali diubah dan terakhir dengan Peraturan Presiden (Perpres) Nomor 95 Tahun 2007 yang di dalamnya terdapat pengaturan mengenai etika yang harus dipatuhi terkait dengan pelaksanaan barang atau jasa, di antaranya, tidak saling mempengaruhi baik langusng maupun tidak langsung untuk mencegah dan menghindari terjadinya persaingan tidak sehat. Beberapa aturan tersebut telah dilanggar oleh PT DGI dalam memenangkan proses lelang yang tentunya tidak sesuai asas itikad baik, asas kepantasan, asas kepatutan serta prinsip-prinsip tata kelola perusahaan yang baik atau yang dikenal dengan good corporate governance (GCG).

Asas-asas di atas tentu perlu diperhatikan dalam suatu korporasi. Misalnya asas itikad baik atau dikenal dengan istilah goodfaith, yaitu asas yang terdapat dalam hukum kontrak, yang diatur dalam Pasal 1338 ayat (3) KUHPerdata yang menyatakan bahwa suatu perjanjian harus dilaksanakan dengan itikad baik. Itikad baik bermakna bahwa kedua belah pihak harus berlaku satu dengan lainnya tanpa tipu daya, tanpa tipu muslihat, tanpa mengganggu pihak lain tetapi juga kepentingan pihak lainnya. ${ }^{20}$ Prinsip itikad baik juga mendasarkan dirinya kepada keadilan yakni keadilan sebagai kepatutan. ${ }^{21}$ Dalam mengadakan suatu perjanjian, kesepakatan hendaknya dilandaskan dengan itikad baik, tidak melanggar peraturan perundang-undangan, serta tidak melanggar kepentingan masyarakat. ${ }^{22}$ Apabila kita melihat yang terjadi pada PT DGI, tentu asas ini tidak selaras dengan apa yang seharusnya dilakukan oleh PT DGI dalam membuat

${ }^{20}$ Ridwan Khairandy, Hukum Kontrak Indonesia Dalam Perspektif Perbandingan, FH UII Press, Yogyakarta, 2013, hlm. 133

${ }^{21}$ Ibid.

${ }^{22}$ Niru Anita Sinaga, "Perjanjian Pengadaan Barang/Jasa Pemerintah Kaitannya Dengan Asas Keseimbangan Dalam Hukum Perjanjian”, Jurnal Ilmiah Hukum Dirgantara Vol. 9 No. 2, Maret 2019, hlm. 10 
kesepakatan terhadap pengaturan proyek pembangunan rumah sakit yang secara sengaja hendak memenangkan PT DGI dalam pelelangan proyek tersebut.

Asas selanjutnya adalah kepantasan dan kepatutan. Asas ini saling terkait dengan asas itikad baik, bahwa suatu perjanjian harus dilaksanakan dengan itikad baik, dan itikad baik harus dilandaskan dengan kepantasan dan kepatutan. Kepantasan dan kepatutan bertujuan untuk mencegah perilaku yang tidak patut dan tidak pantas dalam pelaksanaan suatu perjanjian. Jadi, kepatutan dan kepantasan tidak hanya harus sesuai dengan undang-undang, tetapi juga tidak melanggar kepentingan publik, kebiasaan masyarakat, dan pastinya yang diperjanjikan merupakan sesuatu yang patut dan pantas di hadapan hukum.23 Asas ini tentu tidak sesuai dengan PT DGI yang telah melanggar etika dalam pelaksanaan barang/jasa, perbuatan yang dilakukan oleh PT DGI merupakan sesuatu yang tidak pantas dan tidak patut secara hukum. Dan yang terakhir berkaitan dengan prinsip-prinsip tata kelola perusahaan yang baik (good corporate governance).

Prinsip ini merupakan suatu sistem untuk mengendalikan serta mengatur perusahaan agar dapat menjaga keseimbangan dalam pengendalian perusahaan sehingga nantinya mampu untuk mengurangi terjadinya kesalahan dalam pengelolaan suatu perusahaan. ${ }^{24}$ Prinsip ini pun menyangkut beberapa aspek, yakni keterbukaan informasi (transparency), akuntabilitas (accountability), pertanggungjawaban (responsibility), dan kemandirian (independency). ${ }^{25}$ Aspekaspek tersebut sebagian ada yang dilanggar oleh PT DGI, seperti tidak adanya transparansi dalam melakukan pelaksanaan lelang, kemudian tidak adanya independensi yang tergambar melalui saling mempengaruhi baik langsung maupun tidak langsung dalam proses pelaksanaan lelang tersebut, sehingga tentu akuntabilitas dari suatu perusahaan pun dipertanyakan.

Berdasarkan teori corporate culture model, korporasi bertanggung jawab karena dianggap memiliki budaya yang mendorong atau memberikan toleransi

\footnotetext{
${ }^{23}$ I Gusti Nhurah Anom, "Adendum Kontrak Pemborongan Perspektif Hukum Perjanjian Di Indonesia”, Jurnal Advokasi Vol. 5 No. 2, September 2015, hlm. 185

${ }^{24}$ Rinitami Njatrijani et al., "Hubungan Hukum Dan Penerapan Prinsip Good Corporate Governance Dalam Perusahaan", Jurnal Gema Keadilan, Vol. 6 No. 3, Oktober- November 2019, hlm. 256

${ }^{25}$ Ibid., hlm. 250
} 
pada tindak pidana, atau dianggap gagal untuk membangun budaya yang mendorong adanya penataan terkait dengan budaya kerja suatu korporasi. ${ }^{26}$ Teori ini berkembang karena di dalam berbagai tindak pidana, struktur atau budaya di dalam korporasi sangatlah berpengaruh. Oleh karena itu, berdasarkan argumentasi-argumentasi hukum di atas, dapat dikatakan bahwa kriteria batasan pertanggungjawaban pidana korporasi dalam teori budaya korporasi (corporate culture model) adalah sebagai berikut:

1. Adanya kebijakan, baik secara tersurat maupun tersirat, memaksa, mendorong, mengizinkan, atau memberikan toleransi atas tindak pidana yang dilakukan

Maksudnya adalah apabila terdapat kebijakan korporasi yang secara nyata dapat mendorong terjadinya suatu pelanggaran ataupun mengizinkan untuk dilakukannya tindak pidana. Misalnya saja seorang karyawan harus melakukan tindakan yang melanggar aturan, hal tersebut terpaksa ia lakukan karena dirinya merasa terancam akan kehilangan pekerjaannya. Dengan demikian, dalam hal ini, sebagai suatu keseluruhan, korporasi adalah pihak yang bertanggung jawab karena telah dilakukannya perbuatan yang melanggar hukum dan bukan orang yang telah melakukan perbuatan itu saja bertanggung jawab, tetapi juga korporasi tempat orang itu bekerja. Kesalahan korporasi berdasarkan kriteria ini terletak pada niatan korporasi untuk benar-benar mengizinkan atau memberikan toleransi atas terjadinya suatu tindak pidana yang dilakukan pengurus dan pegawai atau pekerja korporasi melalui kebijakan, baik tersurat maupun tersirat.

\section{Adanya budaya yang mengarahkan, mendorong, atau memberikan toleransi pada dilakukannya tindak pidana}

Kriteria yang kedua ini menerangkan bahwa korporasi memiliki budaya kerja yang tidak sehat, seperti perbuatan-perbuatan yang tidak sesuai dengan aturan, yakni melakukan kecurangan-kecurangan, kebohongan, penyembunyian fakta, manipulasi, dan lain sebagainya sehingga mengakibatkan tidak dipenuhinya ketentuan peraturan perundang-undangan terkait. Budaya kerja yang terdapat dalam perusahaan itu sendirilah yang menyebabkan ketidakpatuhan dengan peraturan-peraturan terkait atau dengan kata lain

${ }^{26}$ Kristian, Sistem Pertanggungjawaban Pidana Korporasi..., Op. Cit., hlm. 100 
perusahaan gagal menciptakan suatu budaya kerja yang baik dalam internalnya sendiri. Dengan demikian, budaya kerja yang tidak sehat tersebut menjadi hal yang biasa mereka lakukan karena memang sudah menjadi tabiat mereka dalam bekerja. Kebiasaan-kebiasaan buruk yang demikian lambat laun akan beurjung pada terjadinya suatu pelanggaran hukum. Hal ini tentu bertentangan dengan asas itikad baik, asas kepantasan, asas kepatutan serta prinsip-prinsip tata kelola perusahaan yang baik yang seharusnya menjadi landasan dalam mengoperasikan suatu korporasi.

Apabila dicermati, maka kesalahan korporasi pada kriteria ini didasarkan pada budaya kerja korporasi itu sendiri yang secara tidak langsung sebenarnya mendorong untuk dilakukannya berbagai perbuatan-perbuatan yang melanggar ketentuan peraturan perundang-undangan.

\section{Adanya kegagalan untuk menerapkan program penataan atau untuk melaksanakan upaya pencegahan terhadap tindak pidana}

Kriteria yang ketiga ini masih ada korelasinya dengan kriteria sebelumnya karena berkaitan juga dengan prinsip-prinsip tata kelola perusahaan yang baik, serta suatu korporasi diharuskan untuk memilihara suatu budaya kerja yang mengharuskan kepatuhan terhadap ketentuan peraturan perundang-undangan. Prinsip tata kelola yang baik dalam suatu korporasi juga sangat dibutuhkan, karena dengan adanya prinsip tersebut setidaknya suatu korporasi dapat membaca situasi ataupun memperkirakan akibat dari keputusan yang diambil; apakah nantinya berindikasi tindak pidana atau tidak, kemudian apakah dapat menimbulkan kerugian bagi negara atau kerugian bagi masyarakat banyak atau tidak.

Selain itu, pada kriteria ini dapat dilihat juga apakah suatu korporasi memiliki whistleblowing system yang dapat digunakan sebagai salah satu bentuk pengawasan oleh perusahaan untuk menjalankan pengendalian secara internal agar konsisten dan berkesinambungan. Whistleblowing system merupakan sistem yang dapat mengungkapkan adanya pelanggaran-pelanggaran dalam suatu korporasi, mencakup penipuan, pelanggaran kode etik perusahaan, dan pelanggaran peraturan perusahaan. Berdasarkan kriteria ini, maka kesalahan 
korporasi dapat dilihat dari tidak adanya tindakan pencegahan yang dilakukan oleh korporasi untuk mencegah terjadinya suatu tindak pidana.

\section{Adanya kegagalan dalam mengambil tindakan pencegahan guna merespon tindak pidana yang dilakukan}

Kriteria ini menggambarkan bahwa korporasi harus memperkirakan kemungkinan terjadinya suatu tindak pidana. Dengan demikian, korporasi dapat mengambil tindakan pencegahan untuk mencegah terjadinya tindak pidana tersebut. Korporasi setidaknya harus melakukan penertiban di dalamnya, serta benar-benar melakukan pengontrolan terhadap para pegurus dan pegawainya. Apabila suatu perusahaan telah memastikan bahwa mereka telah melakukan langkah-langkah untuk mencegah terjadinya suatu pelanggaran, maka tentu pertanggungjawaban pidana tidak akan dibebankan kepada korporasi yang bersangkutan. ${ }^{27}$ Namun, lain halnya jika pada saat di pengadilan terbukti bahwa suatu korporasi tidak melakukan langkah-langkah yang memadai untuk merespon suatu pelanggaran atau tindak pidana tertentu, maka baik perusahaan ataupun organ dari perusahaan itu akan dibebani pertanggungjawaban pidana atas kelalaian dalam mencegah terjadinya suatu tindak pidana.

Pada kriteria ini, kesalahan korporasi terletak pada kegagalan korporasi untuk menanggapi ataupun merespon sebagaimana mestinya terkait dengan kebijakan-kebijakan di dalam korporasinya sendiri, melakukan tindakan-tindakan penertiban secara internal, serta melakukan pengontrolan terhadap para pegawainya atau pengurus korporasi lainnya.

\section{Penutup}

Pengaturan pertanggungjawaban pidana korporasi yang terdapat dalam Pasal 4 ayat (2) Peraturan Mahkamah Agung Nomor 13 Tahun 2016 tentang Tata Cara Penanganan Perkara Tindak Pidana oleh Korporasi masih memiliki persoalan yang terletak pada tidak jelasnya kriteria batasan dan tidak tegasnya tolak ukur pertanggungjawaban pidana korporasi yang diatur dalam pasal tersebut. Persoalan dalam pasal tersebut dapat dijawab menggunakan teori vicarious liability, yang pertanggungjawaban pidana korporasi dapat dimintakan

${ }^{27}$ Sutan Remy Sjahdeini, Op. Cit., hlm. 191 
apabila adanya mens rea dari orang yang berasosiasi dengan korporasi dalam melakukan tindak pidana harus dengan sengaja dan bertujuan untuk menguntungkan korporasi. Juga, persoalan ini dapat dilihat dari sudut pandang teori corporate culture model, yang korporasi bertanggungjawab karena dianggap memiliki budaya yang mendorong atau memberikan toleransi pada tindak pidana, atau dianggap gagal untuk membangun budaya yang mendorong adanya penataan terkait dengan budaya kerja suatu korporasi.

Saran yang dapat Penulis berikan terkait dengan pemaparan sebelumnya, yakni perlunya pengaturan tolak ukur atau kriteria pertanggungjawaban pidana korporasi dengan jelas dan tegas, mengingat sampai saat ini salah satu masalah yang dihadapi dalam kasus yang melibatkan korporasi adalah adanya kebimbangan dalam mengadressatkan pertanggungjawaban pidana tersebut terhadap korporasi. Dalam hal ini pengaturan mengenai kebijakan korporasi masih tidak mempunyai keseragaman dalam bentuk pengaturannya, sehingga tidak hanya dibutuhkan pengaturan dari segi hukum materil, tetapi juga dari segi formil yang diakomodir dalam RUU KUHAP.

\section{Daftar Pustaka}

\section{Buku}

Arief, Barda Nawawi, Perbandingan Hukum Pidana Edisi Revisi, PT Rajagrafindo, Jakarta, 2019.

Bunga Rampai Kebijakan Hukum Pidana (Perkembangan Penyusunan Konsep KUHP Baru), Prenadamedia Group, Jakarta, 2016.

Khairandy, Ridwan, Hukum Kontrak Indonesia Dalam Perspektif Perbandingan, FH UII Press, Yogyakarta, 2013.

Kristian, Sistem Pertanggungjawaban Pidana Korporasi (Tinjauan Teoritis Dan Perbandingan Hukum Di Beberapa Negara), PT Refika Aditama, Bandung, 2016.

Muladi dan Dwidja Priyatno, Pertanggungjawaban Pidana Korporasi, Prenadamedia Group, Jakarta, 2010.

O. S. Hiariej, Eddy, Prinsip-Prinsip Hukum Pidana, Cahaya Atma Pusaka, Yogyakarta, 2016.

Sjahdeini, Sutan Remy, Ajaran Pemidanaan Tindak Pidana Korporasi E Seluk Beluknya, Kencana, Jakarta, 2017. 


\section{Jurnal}

Anindito, Lakso, "Lingkup Tindak Pidana Korupsi Dan Pembuktian Kesalahan Dalam Sistem Pertanggungjawaban Pidana Korporasi Di Indonesia, Inggris, Dan Perancis", Integritas Jurnal Anti Korupsi, Vol. 3, No. 1, Maret 2017.

Anom, I gusti Nhurah, "Adendum Kontrak Pemborongan Perspektif Hukum Perjanjian Di Indonesia", Jurnal Advokasi, Vol. 5, No. 2, September 2015.

Disemadi, Hari Sitra., dan Nyoman Serikat Putra Jaya. "Perkembangan Pengaturan Korporasi Sebagai Subjek Hukum Pidana Di Indonesia." Jurnal Hukum Media Bhakti, Vol. 3, No. 2, 2019.

Kristian, "Urgensi Pertanggungjawaban Pidana Korporasi", Jurnal Hukum $\mathcal{E}$ Pembangunan, Vol. 44, No. 4, Desember 2013.

Njatrijani, Rinitami, Bagus Rahmanda, Reyhan Dewangga Saputra, "Hubungan Hukum Dan Penerapan Prinsip Good Corporate Governance Dalam Perusahaan", Jurnal Gema Keadilan, Vol. 6, No. 3, Oktober-November 2019.

Rahmadia, Fitriani, Hari Sutra Disemadi, and Nyoman Serikat Putra Jaya. "Criminal Liability in Environmental Crimes Committed by Corporations after the Supreme Court Regulation Number 13 of 2016 at Indonesia." Unram Law Review, Vol. 4, No. 1, 2020.

Satria, Hariman, "Pertanggungjawaban Pidana Korporasi Dalam Tindak Pidana Korupsi", Jurnal Mimbar Hukum, Vol. 28, No. 2, Juni 2016.

Sinaga, Niru Anita. "Perjanjian Pengadaan Barang/Jasa Pemerintah Kaitannya Dengan Asas Keseimbangan Dalam Hukum Perjanjian." Jurnal Ilmiah Hukum Dirgantara, Vol. 9, No. 2, Maret 2019.

Suhariyanto, Budi, "Kedudukan Peraturan Mahkamah Agung Nomor 13 Tahun 2016 Dalam Mengatasi Kendala Penanggulangan Tindak Pidana Korporasi", Negara Hukum: Membangun Hukum Untuk Keadilan Dan Kesejahteraan, Vol. 9, No. 1, Juni 2018.

Wibisana, Andri G, "Kejahatan Lingkungan Oleh Korporasi: Mencari Bentuk Pertanggungjawaban Korporasi Dan Pemimpin/Pengurus Korporasi Untuk Kejahatan Lingkungan Di Indonesia", Jurnal Hukum $\mathcal{E}$ Pembangunan, Vol. 46, No. 2, April-Juni 2016.

\section{Internet}

"Eks Dirut PT DGI Dudung Purwadi Divonis 4 Tahun 8 Bulan Bui", https://nasional.tempo.co/read/1037507/eks-dirut-pt-dgi-dudungpurwadi-divonis-4-tahun-8-bulan-bui, diakses pada tanggal 18 November 2018.

\section{Perundang-Undangan}

Undang-Undang Nomor 40 Tahun 2007 Tentang Perseroan Terbatas, Lembaran Negara Republik Indonesia Tahun 2007, Tambahan Lembaran Negara Republik Indonesia Nomor 4756. 
Peraturan Pemerintah Nomor 29 Tahun 2000 Tentang Penyeleggaraan Jasa Konstruksi, Lembaran Negara Republik Indonesia Tahun 2000, Tambahan Lembaran Negara Republik Indonesia Nomor 3956.

Keputusan Presiden Nomor 80 Tahun 2003 Tentang Pedoman Pelaksanaan Pengadaan Barang/Jasa Pemerintah, Lembaran Negara Republik Indonesia Tahun 2003, Tambahan Lembaran Negara Nomor 4330.

Peraturan Mahkamah Agung Nomor 13 Tahun 2016 Tentang Tata Cara Penanganan Perkara Tindak Pidana Oleh Korporasi, Lembaran Negara Republik Indonesia Tahun 2016, Tambahan Lembaran Negara Nomor 2058.

\section{Putusan Pengadilan}

Putusan Pengadilan Negeri Jakarta Pusat Nomor: 94/Pid-Sus-TPK/2017/PN. Jkt. dalam Perkara Dudung Purwadi. 